\title{
Key Issues on Informal Learning in the 21st Century: A Text Mining-based Literature Review
}

\author{
https://doi.org/10.3991/ijet.v16i17.23663 \\ Kyung-Hee Park, He Li( $\left.{ }^{\bowtie}\right)$, Nan Luo \\ Woosuk University, Jeollabuk-do, South Korea \\ lihehe.kr2020@gmail.com
}

\begin{abstract}
This study aimed to reveal the key issues and trends of informal learning in the 21st century through reviewing literature published between 2000 and 2020. This study adopted a systematic text mining-based analysis to explore the wide-scale and in-depth study on informal learning. The result showed the main issues in informal learning, including participants and educational need, environment, process, and research turnings over time. In addition, informal learning has played an active and significant role in the digital era of the 21st century, and its educational effects are expanding even further in recent years. Then, we provided a broad perspective to a frame of future informal learning research.
\end{abstract}

Keywords - informal learning, work, activity, student, literature review

\section{Introduction}

Digital revolution has transformed massively the world of education, the transformation is much like the transition from apprenticeship to universal schooling being promoted by 19th century industrial revolution [1]. In a world characterized by rapid change due to digitization and the transition towards a global knowledge-based service economy, a key challenge for educational and training systems is to ensure that people can access opportunities to upskill and reskill [2]. Additionally, learning activities always occur "anywhere, anytime" in the digital era. Informal learning has greater flexibility or freedom for learners contrasted to formal learning or training. As an inseparable part of lifelong learning, informal learning has become an ever more important way to meet the challenge in a fast-changing world.

Given the importance of learning to economic and life success, Van, James and Bedley [3] seek to broaden the conception of learning beyond traditional formal education and adopts term "informal learning" to refer the learning occurs everyday in a variety of settings including classroom, work, home, and community. Informal learning plays an impact on individuals, organizations, and the economy in many ways that can significantly promote the success in today's society. Moreover, Enos, Kehrhahn and Bell [4] prove that 70 percent of the learning activities pertained to informal learning through study on managers engaged in informal learning. Eraut [5] finds that informal support from people on the space is more useful to the maturer than assist guide from 
formally nominate instructors. Rogers [6] uncovers informal learning occupies a large part of the whole learning process and plays a critical role for economic and life success.

Education is a lifelong endeavor, and most people's schooling covers only the ages of 5 to 18 and 21. Even students are at school, most of their meaningful education occurs beyond school [1]. In order to meet the challenge of rapid change of world, student needs to participate in activities that gain knowledge or skills from experience, action, feedback seeking, and reflection.

Informal learning also connects closely with the studies on participants, contents and ways of education. Lanier [7] points that teacher's primary responsibility is to find and construct significant educational experiences that enable students to solve problems occurred in reality and demonstrate that students have learned the important ideas, practical skills, and habits of thinking that meet accepted educational standards. Then, student could practice the abstract, inert knowledge of textbooks into the creation and extension of new knowledge in real setting. Therefore, teachers should realize the necessity and urgency of informal learning. Moreover, learning is a lifelong task and effective way to deal with changing environment. Graduation from school for individual, may only mean the accomplishment of formal learning, rather than the end of lifelong learning. If individual wants to adapt to the fast developing society, he/she should keep learning more extensive and comprehensive new knowledge and skills via informal learning. Informal and situated learning at work is being given increasing attention within national research and development agendas, and throughout Europe in particular [8].

Formal learning is insufficient for reliable training transfer, and formal learning alone may not be the most effective method to achieve behavior change [9]. Therefore, research on informal learning has been carried out in many professional contexts [10], [11] and [12]. Informal learning provides opportunity to learners to the practice knowledge derived from formal training in the everyday workplace setting. Even the effective use of informal learning will have a beneficial impact on the whole lifelong learning. By way of summary, informal learning is becoming more and more important, so that the study on informal learning is becoming urgent and necessary.

Therefore, the study attempted to review the research trends, and extended the key issues on informal learning in the 21 st century. Aiming at providing a broader view through key issues, this study revealed a literature analysis based on text mining for informal learning research, from 2000 to 2020. The main research objectives of this study could be used to analyze the statistical distribution of published articles in the 21 st century and to classify research topics and trends according to systematic taxonomies that reflect patterns of informal learning research. The findings contributed in many ways to informal knowledge learning systems by providing a broad view on the comprehending of research topics and trends.

\section{Theoretical background}

\subsection{Definitions and models of informal learning}

Tough [13] observed that informal learning is the submerged part of the iceberg of adult learning activities. Studies also confirmed that, for numerous adults, informal 
learning represented the vital form of learning to cope with changing environment; and most job-related learning was done informally [14]. The interest in informal learning had increased since the 1990s [5], [14]. Informal learning aimed at knowledge or skills were individually or group determined and it was commonly estimated that 70-90\% of human learning fell into this category [15]. Informal learning was repeatedly defined by contrasting and comparing it with formal learning and non-formal learning [5].

Unlike the institutionalized methods, informal learning is omnipresent [16], [17]. OECD [18] defined that informal learning resulted from daily life activities related to work, family or leisure activities was never organized, has no set objective in terms of learning outcomes and was never intentional from the learner's standpoint. This definition met with a fair degree of consensus. Informal learning was often spontaneous, unplanned and unstructured [19], [17], [20]. As it was not structured (in terms of learning objectives, learning time or learning support), so informal learning typically did not lead to certification. Informal learning might be intentional but in most cases it was non-intentional [21]. Moreover, Schugurensky [17] also identified 3 types of informal learning: self-directed learning (intentional and conscious), incidental learning (unintentional but conscious) and socialization or tacit learning (unintentional and unconscious process) by employing two main categories (intentionality and consciousness) from the perspective of taxonomy.

Furthermore, some scholars also pointed that initiated by learners, happened on a need-based basis, was inspired by developmental intentions, entailed performance and reflection, and does not occur in a formal classroom environment [22], [23]. Actually, Nygren et al. [24] pointed out informal learning existed inside and outside of formal education. When educational institutions engaged in informal learning, it was not based on classroom activities and is unnecessarily structured. Informal learning also took place in other formal environments, such as networks, tutoring and mentoring [20]. Obviously, informal learning was more extensive than formal and informal learning [25]. Some people believed that informal learning activities are more important than formal and non-formal activities [26]. It was generally believed that informal learning has an impact on lifelong learning [27].

\subsection{Literature trends for informal learning}

In the 21 st century, the literature showed the various aspects of informal learning had been involved in the range of extensive and in-depth academic discussions. Regarding to the subjects of informal learning, the pilot studies focused on students and teachers, including K-12 and university students [28], [29], [30]; new and experienced teachers [31], [32], [33], [34]; doctors and nurses [35], [36]; and other diverse types of workplace informal learning in every industries, such as trade unions, investment bank, and other informal cooperative learning environment [37], [38], [39].

Combined with the professional requirements of every industries, scholars also performed scientific and comprehensive studies and analysis on the impact factors of informal learning occurs at schools or workplaces. For example, in the study of the teachers' informal learning, Lohman [33] found the environmental inhibitors to informal learning in the workplace for public school teachers. Besides, Lohman [40], Melber and Cox-Petersen [41] provided the practical implications for facilitating informal workplace learning. Furthermore, in certain workplace, Schürmann and Beausaert [42] 
found the supervisor and collaboration at workplace influenced the effectiveness and outcomes of informal learning.

Regarding to the settings or environments of informal learning, this study confirmed its various characteristics and new forms with the rapid technology, internet and social media advancement. Informal learning was used increasingly to describe the out-ofschool learning in loosen organizational form as learning not only takes place in the formal classroom, but everywhere [43]. The informal learning could occurs in the physical environments, such as the classroom, library, and museum [44], [28], implied that classroom science teaching and informal learning settings showed critical effects on students' abilities of scientific reasoning. Furthermore, in recent years, virtual space basing on the widespread network became platform for the running of informal learning beyond the limitation of time, space and location. For example, Social Network Service (SNS), as an informal learning tool, was available for improvement in student's knowledge and learning experience [45]. Besides, Akkara et al. [46] brought implications that WhatsApp, a representative of social media, had significant impact for interaction in improving the second language speaking skills beyond the classroom. From the perspective of globalization, the concerning of informal learning had not only in one school, one workplace, or one country. However, more and more countries realize that the informal learning was a significant theme for the 21 st century knowledge economic society. Scholars also concentrated on the current situation and propose implication according to studies on informal learning. For example, Fahr [47] found a positive correlation between the level of schooling and time investments in informal learning from Germany's data. Livingstone [14] made an analysis of the results of the first country-wide survey of the informal learning practices of adults in Canada, conducted in 1998. Moreover, the scholars from UK, Australia, Denmark and other countries also provided enrichment literature in the study field of informal learning.

For the outcome of informal learning of subjects, informal learning owned great and positive effects on the improvement of students' achievement and the promotion of teachers' professional development in the settings related with formal learning via informal modes. Martin [43] suggested students' performance and achievement could be promoted by the integration study of Science, Technology, Engineering, and Mathematics (STEM) through the informal learning occurring in non-school setting. Moreover, in the college context, Edwards and Muir [48] criticized the situation and weakness existing in the practice of enterprise education and offer implication on the continuation between undergraduates and post-graduates. For teachers' informal learning, Melber [41] and Rehm [49] discussed the function of informal learning setting/environment, such as, museum, and social media tools. For example, Twitter can contribute to the continuous professional development of teachers by initiating and fostering informal learning. For the measurement of informal learning outcome, Brian et al. [28] developed the Informal Learning Opportunities Assay (ILOA) as an instrument to in the field from middle and high school students. The instrument had been found to provide a reliable assessment of informal learning opportunities. What's more, Svensson et al. [44] pointed that the blending of informal and formal learning is essential in order to create valuable capacities, no matter for organizations or individuals from the studies carried out in two settings: industrial and hospital context. Recently, Nehiri and Aknin 
[50] presented a learner's data model integrating informal learning and enhancing personalization and interoperability. Furthermore, informal learning also brought impetus on the progress of community and society, and even for the global development.

Through previous researches on informal learning, the coverage and scholars' contribution of the research (the subjects, learning setting/environment, and influential factors, outcome, measurement and other related aspects of informal learning) became clearly.

\section{Methods}

The study aimed to identify the major issues and trends of research related to informal learning. The systematic literature review method was chosen as the most suitable method because it reduces the potential internal bias with a scientific method [51]. So, this research method consisted of main steps: search process, inclusion and exclusion, main data extraction, and generalization and structured.

\subsection{Data collection}

Data collection as search process defined the search criteria from the start, selects published research data, and provides summary information on the existing literature.

First of all, in order to ensure that relevant studies were located, a wide variety of databases (Web of Science, Springer, Scopus, SAGE and Google scholar) were searched, and systematically reviewed the article databases on previous studies related to "informal learning". Among the searched articles, we excluded literature that was not regularly reviewed, such as book review and academic conference material. And they were conducted crosswise comparison of the pre-searched articles to avoid duplication. In order to narrow down study objective under informal learning in the $21 \mathrm{st}$ century, we selected the database from 2000 to 2020. As a result, a total of 239 articles were collected from 337 SSCI and Scopus level articles on informal learning.

\subsection{Data analysis}

In this study, a text mining analysis was performed to primarily explore the key issues on informal learning in articles, there are 4 steps for analysis. Step 1 was to select optimized articles to collect trends and major issues of research related to informal learning. Finally, a total of 231 abstracts were remained from 239 articles on informal learning.

Step 2 was the keywords cording and cleaning, so that core concepts appropriate for the study purpose can be derived from the articles. The keywords presented in the literature data were applied to the analysis as they were, but the final keywords were derived through the following refinements. The keywords were derived by means of a cleaning process, such as removing spaces from the main words or applying a quotation mark. The keywords could be classified with similar meanings, then were unified as representative words those could be used with a comprehensive meaning.

Step 3 was data regularization, text processing rules and concept seed settings were ensured to produce more meaningful and related results. The study implemented one 
sentence as coding units and abstracts itself as context units. It also removed seed terms with weak semantic information and specific words from the data to ensure general concepts. This process was to adjust that high-frequency, low-semantic words would not impact the seed selection [51]. The study identified 4,095 keywords, and deleted nodes with unclear meanings and words that occurred fewer than 10 times. Ultimately, 3,232 keywords that appeared more than 10 times were derived from the refining process.

As step 4, statistical program was used to analyze using text mining, and to construct the conceptual words to be displayed on the results from articles. 'Term Frequency (TF)' and 'Term Frequency-Inverse Document Frequency (TF-IDF)' were calculated using the R program (open-source software program) for the main keyword frequency analysis. For example, the words used in the analysis were corrected to the original words, and the results were rearranged in the order of the highest significance.

\section{$4 \quad$ Results}

\subsection{Systematic literature review}

The systematic review was conducted to better describe literature set to show details such as annual distributions and issue areas. First, the publication of informal learning articles was continuously revealed by years. Table 1 shows the literature distribution according to year between 2000 and 2020.

Table 1. Annual distribution and examples of articles

\begin{tabular}{|c|c|c|c|c|c|c|c|c|c|c|c|c|c|c|c|c|c|c|c|c|c|}
\hline Year & ఫ్తి & હ্ণ & હ્ণ & ఫ্ণ & ๕ి & ङ્తి & હิ) & $\stackrel{\infty}{\stackrel{\overbrace{}}{్}}$ & હે & 을 & 三 & 공 & $\stackrel{\text { त) }}{\bar{乛}}$ & ষ্ণ & 胥 & 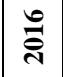 & 공 & $\stackrel{\infty}{\stackrel{\sim}{\tilde{~}}}$ & $\stackrel{\mathrm{\sigma}}{\overline{\mathrm{N}}}$ & ণิ & है \\
\hline $\begin{array}{c}\text { Fre- } \\
\text { quency }\end{array}$ & 6 & 5 & 5 & 6 & 5 & 5 & 7 & 10 & 11 & 7 & 12 & 17 & 20 & 22 & 16 & 24 & 16 & 12 & 19 & 14 & 239 \\
\hline Ratio (\%) & (2.5) & (2.1) & (2.1) & (2.5) & (2.1) & (2.1) & (2.9) & $(4.2)$ & (4.6) & (2.9) & (5.0) & (7.1) & (8.4) & $(9.2)$ & (6.7) & (10.0) & $(6.7)$ & (5.0) & (7.9) & (5.9) & $(100.0)$ \\
\hline
\end{tabular}

As seen in Figure 1, it is revealed that the number of articles are increasing systematically each year. In particular, starting in 2011, there has been a significant change in the number of articles, and in recent years, the increasing trend has also changed slightly. It showed the highest distribution in 2016, but decreased overall after that. However, the overall distribution was confirmed as an increasing trend. 


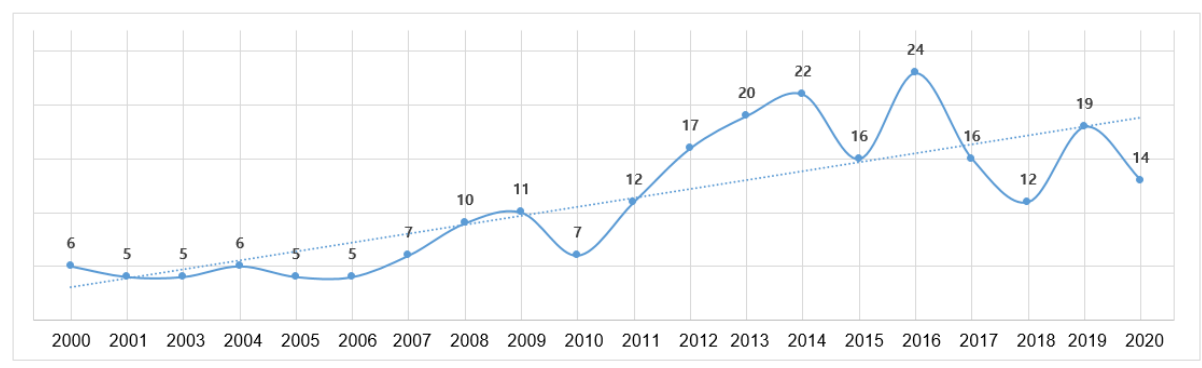

Fig. 1. Annual distribution of articles

Next, article distribution related to the main subject areas, such as pedagogy and andragogy, was confirmed. In particular, pedagogy included higher education from k12 , and andragogy covered all types of education for adults, including education in the workplace. Figure 3 and Table 2 reveal that among the 239 articles analyzed, $43.1 \%$ (103 articles) were under andragogy and vocational subject area. Next, $37.6 \%$ of them (90 articles) were under pedagogy issue area and $15.5 \%$ (37 articles) become e-learning issue area. The other areas had less than $4 \%$ articles, and they were mainly articles pedagogy and andragogy combined.

In addition, it was worth noting that there were the most articles on andragogy, concern in interaction and interpersonal relationships of adults was high. There were several articles on informal learning related to teacher profession and expertise in the pedagogy subject area. In the e-learning subject area, the development of tools for implementing informal learning in an online environment was mainly discussed.

Table 2. Distribution of articles by subject area

\begin{tabular}{|l|c|c|c|c|c|}
\hline \multicolumn{1}{|c|}{ Subject } & $\begin{array}{c}\text { Pedagogy } \\
\text { (+higher education) }\end{array}$ & $\begin{array}{c}\text { Andragogy } \\
\text { (+vocational education) }\end{array}$ & E-learning & Etc & Total \\
\hline Frequency & 90 & 103 & 37 & 9 & 239 \\
\hline Ratio (\%) & $(37.6)$ & $(43.1)$ & $(15.5)$ & $(3.8)$ & $(100.0)$ \\
\hline
\end{tabular}

Figure 2, expanded from Figure 1, shows the distribution of the subject area of articles by period. The area of pedagogy and andragogy has been maintained since 2000; especially, the andragogy area has increased significantly since 2012. In addition, in recent years, the increasing trend was more pronounced in the pedagogy than andragogy. The e-learning area showed a distinct difference from the entire distribution, but there has been a tendency to decrease continuously since 2016. Recently, the distribution of articles related to andragogy was confirmed to be the highest. 


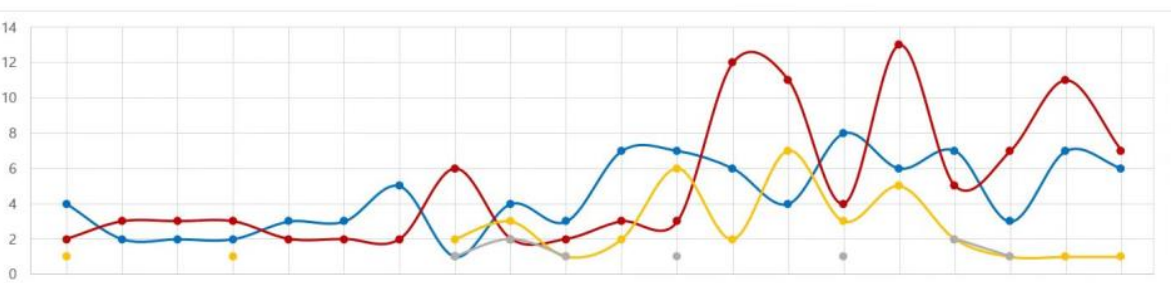

$2000200120032004 \quad 200520062007 \quad 2008 \quad 20092010 \quad 2011 \quad 2012 \quad 2013 \quad 2014 \quad 2015 \quad 2016 \quad 2017 \quad 2018 \quad 20192020$

$\rightarrow$ - pedagogy(higher edu) $\rightarrow$-andragogy(vocational edu) $\rightarrow-$ e-learning $\rightarrow$-etc

Fig. 2. Distribution of subject areas by period

Table 3. Annual distribution and examples of article by subject area

\begin{tabular}{|c|c|c|c|c|c|c|c|c|c|c|c|c|c|c|c|c|c|c|c|c|c|}
\hline $\mathbf{S}$ & ఫ్ & હે & 气్సి & ఫ్ & ڤ̊ํํ & 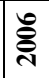 & હે & ڤ્స & ڤ્సે & 을 & $\overline{\bar{g}}$ & בิ) & $\stackrel{m}{\vec{\sim}}$ & অ্ন & 誉 & 울 & $\stackrel{\overline{\mathrm{N}}}{\mathrm{i}}$ & $\stackrel{\infty}{\stackrel{\text { N }}{*}}$ & 롱 & సิ & 苞 \\
\hline & 4 & 2 & 2 & 2 & 3 & 3 & & & 4 & 3 & 7 & 7 & 6 & 4 & 8 & 6 & 7 & 3 & 7 & 6 & 90 \\
\hline And & 2 & 3 & 3 & 3 & 2 & 2 & 2 & 6 & 2 & 2 & 3 & 3 & 12 & 11 & 4 & 13 & 5 & 7 & 11 & 7 & 103 \\
\hline E-lec & & & & 1 & & & & 2 & 3 & 1 & 2 & 6 & 2 & 7 & 3 & 5 & 2 & 1 & 1 & 1 & 37 \\
\hline Etc & & & & & & & & 1 & 2 & 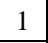 & & 1 & & & 1 & & 2 & 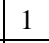 & & & 9 \\
\hline otal & 6 & 5 & 5 & 6 & 5 & 5 & 7 & 10 & 11 & 7 & 12 & 17 & 20 & 22 & 16 & 24 & 16 & 12 & 19 & 14 & 239 \\
\hline
\end{tabular}

\subsection{Keyword frequency in literature}

Table 4 shows the conceptual issued keywords displayed from 239 articles on informal learning, and finally identified 3,232 keywords. The result for "Informal learning" was the highest, but because "informal learning" as selected as the main search keyword, it could not be considered. So the results were confirmed that "activity", "teacher", "work", "develop" and "process" showed high values from the keyword frequency analysis. Obviously, the research frequency of work-related informal learning was very high, indicating that researchers have noticed the importance and necessity of informal learning for work. In addition, we also found that the frequency of "social" was even higher than that of "school", indicating that when individuals graduate from school and enter society, the connection between "informal learning" and "social" became close.

Table 4. Keyword frequency

\begin{tabular}{|l|c|c|c|c|c|c|c|}
\hline No. & Keyword & TF & TF-IDF & No. & Keyword & TF & TF-IDF \\
\hline 1 & Informallearning & 518 & 172.569 & 16 & practice & 96 & 139.708 \\
\hline 2 & Student & 168 & 235.721 & 17 & school & 91 & 146.459 \\
\hline 3 & Activity & 165 & 196.380 & 18 & technology & 86 & 147.872 \\
\hline 4 & Teacher & 149 & 256.196 & 19 & engage & 83 & 137.116 \\
\hline
\end{tabular}




\begin{tabular}{|l|c|c|c|c|c|c|c|}
\hline 5 & Work & 138 & 153.344 & 20 & workplace & 83 & 140.805 \\
\hline 6 & Develop & 135 & 126.541 & 21 & individual & 78 & 127.178 \\
\hline 7 & Process & 129 & 155.312 & 22 & group & 71 & 136.696 \\
\hline 8 & Formal & 113 & 149.358 & 23 & environment & 70 & 114.134 \\
\hline 9 & Knowledge & 113 & 136.049 & 24 & understand & 69 & 101.658 \\
\hline 10 & Social & 107 & 134.941 & 25 & different & 64 & 104.351 \\
\hline 11 & experience & 106 & 141.775 & 26 & interaction & 64 & 117.955 \\
\hline 12 & organization & 106 & 156.170 & 27 & employee & 62 & 135.458 \\
\hline 13 & professional & 101 & 166.852 & 28 & effect & 61 & 106.321 \\
\hline 14 & context & 99 & 133.997 & 29 & online & 60 & 119.048 \\
\hline 15 & support & 99 & 130.854 & 30 & information & 58 & 116.864 \\
\hline
\end{tabular}

In the results of Figure 3 and Table 5, text mining by period, discussions related to the "workplace" such as "work" and "professional" were majors before 2010, but various discussions were found since then. In contrast, the diversity of informal learning after 2010 is as follows. Various methods for facilitating and managing new "knowledge" have been introduced, and there have been many discussions about acquiring meaningful "technology", especially in the "online" experience. From 2011 to 2016, "social" and "interaction" appeared relatively high, it suggested that interaction activities between an intermedium and an object can be a means of engaging in informal learning. In addition, a number of studies described interactions among learners were included in them. And during this period, "different" informal learning environments and approaches were emphasized and it was a period when discussions about IT technology-enhanced informal learning and e-learning spread. Since 2017, studies on the "effect" of informal learning have increased sharply, in hence, quantitative studies have increased. In addition, they highlighted effective "performance" to facilitate student or learner' activities in their informal learning. In recent period, trends related to the comparison of effects with "formal education" have also been extended.

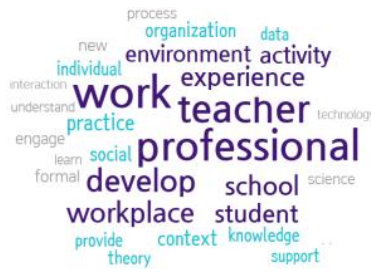

2000-2010

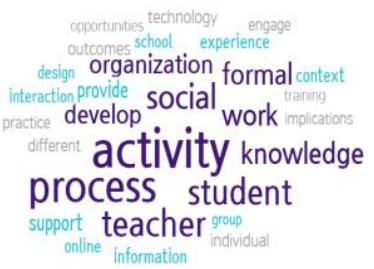

2011-2016

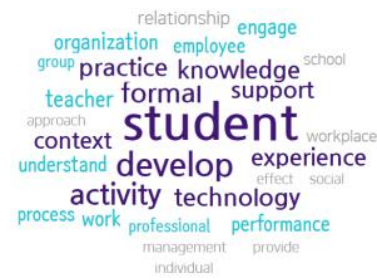

$2017-2020$

Fig. 3. Word cloud by year period

Table 5. Keyword frequency by year period

\begin{tabular}{|l|c|c|c|c|c|c|c|c|c|}
\hline \multirow{2}{*}{ No. 2000-2010 } & \multicolumn{3}{|c|}{} & \multicolumn{3}{c|}{ 2011-2016 } & \multicolumn{2}{c|}{ 2017-2020 } \\
\cline { 2 - 10 } & Keyword & TF & $\boldsymbol{T F}$-IDF & Keyword & $\boldsymbol{T F}$ & $\boldsymbol{T F}$-IDF & Keyword & $\boldsymbol{T F}$ & $\boldsymbol{T F}$-IDF \\
\hline 1 & informallearning & 127 & 39.735 & informallearning & 223 & 73.033 & informallearning & 168 & 58.745 \\
\hline 2 & work & 53 & 52.248 & Activity & 91 & 107.668 & student & 73 & 74.448 \\
\hline
\end{tabular}




\begin{tabular}{|c|c|c|c|c|c|c|c|c|c|}
\hline \multirow{2}{*}{ No. } & \multicolumn{3}{|c|}{ 2000-2010 } & \multicolumn{3}{|c|}{ 2011-2016 } & \multicolumn{3}{|c|}{$2017-2020$} \\
\hline & Keyword & $T F$ & $T F-I D F$ & Keyword & $T F$ & $T F-I D F$ & Keyword & TF & TF-IDF \\
\hline 3 & professional & 51 & 76.329 & Process & 79 & 93.470 & develop & 49 & 33.167 \\
\hline 4 & teacher & 49 & 70.173 & Teacher & 65 & 121.961 & activity & 44 & 46.919 \\
\hline 5 & develop & 39 & 36.917 & Student & 64 & 98.014 & formal & 41 & 54.870 \\
\hline 6 & workplace & 35 & 50.124 & Social & 59 & 69.807 & practice & 38 & 46.379 \\
\hline 7 & school & 33 & 51.666 & knowledge & 52 & 63.077 & technology & 38 & 48.551 \\
\hline 8 & experience & 33 & 43.373 & Work & 52 & 66.328 & knowledge & 37 & 31.553 \\
\hline 9 & student & 31 & 50.832 & formal & 51 & 66.725 & experience & 36 & 36.714 \\
\hline 10 & activity & 30 & 39.430 & develop & 47 & 51.635 & support & 36 & 33.582 \\
\hline 11 & practice & 28 & 35.287 & organization & 47 & 68.217 & context & 35 & 39.030 \\
\hline 12 & environment & 28 & 41.906 & provide & 41 & 47.321 & teacher & 35 & 63.290 \\
\hline 13 & context & 27 & 37.030 & support & 41 & 57.961 & engage & 34 & 37.915 \\
\hline 14 & social & 25 & 35.803 & context & 37 & 55.154 & organization & 34 & 45.502 \\
\hline 15 & organization & 25 & 40.994 & experience & 37 & 58.239 & work & 33 & 32.188 \\
\hline 16 & knowledge & 24 & 39.354 & information & 36 & 65.490 & performance & 32 & 52.031 \\
\hline 17 & individual & 24 & 34.370 & online & 35 & 63.671 & understand & 32 & 34.123 \\
\hline 18 & provide & 23 & 30.229 & design & 34 & 53.517 & employee & 31 & 50.405 \\
\hline 19 & theory & 22 & 32.926 & interaction & 34 & 58.269 & process & 31 & 30.237 \\
\hline 20 & support & 22 & 36.074 & school & 34 & 55.029 & group & 28 & 50.632 \\
\hline 21 & data & 22 & 28.915 & group & 32 & 61.982 & professional & 28 & 37.472 \\
\hline 22 & new & 21 & 39.944 & individual & 32 & 61.982 & relationship & 28 & 41.211 \\
\hline 23 & formal & 21 & 27.601 & technology & 32 & 61.982 & workplace & 25 & 38.648 \\
\hline 24 & engage & 20 & 42.505 & outcomes & 31 & 58.166 & school & 24 & 39.023 \\
\hline 25 & science & 19 & 49.310 & different & 30 & 48.555 & approach & 23 & 28.072 \\
\hline 26 & process & 19 & 28.436 & practice & 30 & 52.953 & effect & 23 & 37.397 \\
\hline 27 & understand & 17 & 25.443 & engage & 29 & 52.756 & management & 23 & 33.852 \\
\hline 28 & learn & 17 & 27.876 & implications & 29 & 42.092 & provide & 23 & 29.386 \\
\hline 29 & technology & 16 & 30.434 & opportunities & 28 & 56.041 & social & 23 & 28.072 \\
\hline 30 & interaction & 16 & 32.119 & training & 27 & 54.040 & individual & 22 & 30.862 \\
\hline
\end{tabular}

\section{Conclusion}

It is well-known that technology has completely changed our society, and yet technology has been kept on the outskirts of the school, mostly for professional courses. Nygren et al. [24] clearly indicated that over 50\% of adults don't have sufficient skills to effectively cope in a technology-rich environment, and instead, informal learning seems to be closely correlated with adequate problem solving skills.

Although it is perceived that the value of informal learning is being emphasized in the area of lifelong learning, there is insufficient whether this is reflected in empirical and individual studies. The study raised the perception for main issues and trends, and how these international discourses are applied in the research area. Based on the review of articles from 2000 to 2020 about informal learning, we found it has close connection 
with adults' workplace informal learning, students' in-school formal learning and outschool informal learning. The key issues of informal learning that have been studied worldwide over the past 20 years are as follows.

From 2000 to 2010, the keyword "work" appears frequently. Researchers seek to integrate "work" and "informal learning" through "develop". Next, from 2010 to 2016, the high frequency keyword is "activity", it shows researchers shift their focus to the various "activity" and "process" relate with "informal learning". Finally, from 2017 to 2020 , the most frequent keyword is "student" indicates studies focus on the object of education "student" and explore the "develop". However, in this period, the frequency of "teacher" is decreasing. This indicates the relation between "student" and "informal learning" is closer than before. Also, before 2017, as a learning community, research on informal learning among teachers has often dealt with. Additionally, "performance" and "effect" also gain the of researchers' attention in recent years.

Based on these results, it can be reasoned that the future directions in informal learning field will develop to be conducted on these issues. First of all, in regards to andragogy, there were lots of studies on informal learning conducted in the workplace learning, and related keywords appeared in the top values, and this trend will continue in the future. As a related case, researched on informal learning in South Korea mainly dealt with workplace experiences for similar 20 years [52], but the international trends have been discussed relatively diverse. In the context of an international discourse, complex and diverse subjects have emerged from pedagogy to andragogy, and there are distinct from the results of various informal learning related to e-learning. These results imply that the orientation and conceptual characteristics of informal learning may differ from country, and they are also related to the unclear definition of informal learning.

Next, there is a high tendency to regard informal learning as an activity, especially after 2011. This is available to explain how diverse informal learning appears comparing to formal or non-formal education. And it is also by studies that deal with the activities of reading related books, visiting museum, and exploring the internet outside the classroom as educational values [53], [54], [55]. Overall, there have been many and various articles exploring the process of informal learning, including personal experiences. Education is not simply a technical business of well managed information processing, nor even simply a matter of applying learning theories [56]. Education should be a complex pursuit of fitting the educational needs of learners and their processes of cultural experiences.

And noteworthy is that many studies have begun to recognize youth students' various types of learning activities inside and outside the school as informal learning in pedagogy. For example, the studies explored how students use different technologies to perform informal learning activities related to the content of their course. Despite, they emphasized understanding technology to design in informal learning environments where identifying the infrastructure that contributes to the learning environment. In a word, the study finds that researchers have been explored the environment, forms and participants that are most closely related to informal learning, as well as the impact on learners.

Furthermore, compared to the 2000s, the new forms of informal learning integrated with computers, mobile devices, and social media has become widespread in the internet development of technology. The informal learning already has become the daily and necessary for individuals who live and work in 21st century. Meanwhile, researches 
have shown a growing consensus that organizational learning occurs not through formal training but informally, and in an ongoing manner [57]. Accordingly, there is a high possibility that studies verifying the effects of informal learning will be expanded.

This study explored the key issues and trends of informal learning research as a whole without regional boundaries. Based on this, studies that examine and compare the characters of informal learning in each country need to be followed. As in the case of South Korea mentioned, various definitions and awareness between countries lead to an obvious understanding of informal learning.

\section{$6 \quad$ References}

[1] Collins, A. and Halverson, R. (2009). Rethinking Education in the Age of Technology: The Digital Revolution and the Schools. New York: Teacher College Press.

[2] OECD. (2020). Strengthening the Governance of Skills Systems: Lessons from Six OECD Countries, OECD Skills Studies, OECD Publishing, Paris, https://doi.org/10.1787/fe4e3e92 $\underline{-e n}$

[3] Van N., James, H., and Bedley, C. (2016). Reconceptualizing learning: A review of the literature on informal learning, ACT Foundation. Rutgers Education and Employment Research Center.

[4] Enos, M. D., Kehrhahn, M. T., and Bell, A. (2003). Informal learning and the transfer of learning: How managers develop proficiency, Human Resource Development Quarterly, Vol. 14, No. 4, pp. 369-387, https://doi.org/10.1002/hrdq.1074

[5] Eraut, M. (2004). Informal learning in the workplace, Studies in continuing education, Vol. 26, No. 2, pp. 247-273, https://doi.org/10.1080/158037042000225245

[6] Rogers, A. (2014). The classroom and the everyday: The importance of informal learning for formal learning,' Investigar em educação, Vol. 2, No. 1.

[7] Education. Org., (1997). Redefining the role of the Teacher: It's a multifaceted Profession by Judith Track Lanier.

[8] Ravenscroft, A., Schmidt, A., Cook, J., and Bradley, C. (2012). Designing social media for informal learning and knowledge maturing in the digital workplace, Journal of Computer Assisted Learning, Vol. 28, No. 3, pp. 235-249, https://doi.org/10.1111/j.1365-2729.2012. $\underline{00485 . x}$

[9] Boud, D. and Middleton, H. (2003). Learning from others at work: communities of practice and informal learning, Journal of Workplace Learning, Vol.15, No. 5, pp. 194-202, https:// doi.org/10.1108/13665620310483895

[10] Bjørk, I. T., Tøien, M., and Sørensen, A. L. (2013). Exploring informal learning among hospital nurses, Journal of Workplace Learning, Vol. 25, No. 7, pp. 426-440, https://doi.org/ 10.1108/jwl-01-2013-0003

[11] Goldman, E., Plack, M., Roche, C., Smith, J. and Turley, C. (2009). Learning in a chaotic environment, Journal of Workplace Learning, Vol. 21, No. 7, pp. 555-574, https://doi.org/ $\underline{10.1108 / 13665620910985540}$.

[12] Wofford, M.G., Ellinger, A.D. and Watkins, K.E. (2013). Learning on the fly: exploring the informal learning process of aviation instructors, Journal of Workplace Learning, Vol. 25, No. 2, pp. 79-97, https://doi.org/10.1108/13665621311299771

[13] Tough, A. (1978). Major Learning Efforts: Recent Research and Future Directions, Adult Education Quarterly, Vol. 28, No. 4, pp. 250-263, https://doi.org/10.1177/07417136780 $\underline{2800403}$ 
[14] Livingstone, D. W. (2000). Researching expanded notions of learning and work and underemployment: Findings of the first Canadian survey of informal learning practices, International Review of Education, Vol. 46, No. 6, pp. 491-514.

[15] Cofer, D. (2000). Informal workplace learning: Practice application brief, NO 10. US Department of Education: Clearinghouse on Adult, Career and Vocational Education.

[16] Eshach, H. (2007). Bridging in-school and out-of-school learning: Formal, non-formal, and informal education, Journal of science education and technology, Vol. 16, No. 2, pp. 171190, https://doi.org/10.1007/s10956-006-9027-1

[17] Schugurensky, D. (2000). The form of informal learning: Towards a conceptualization of the field (W ALL Working Paper No. 19). Toronto, CN: Toronto Ontario Institute for Studies in Education of the University of Toronto.

[18] Werquin, P. (2007). Terms, Concepts and Mdels for Analysing the Value of Recongnition Programmes, EDU/EDPC(2007)24.

[19] Cedefop. (2014). Terminology of European education and training policy: A selection of 130 terms (2nd ed). Luxembourg: Publications Office.

[20] Marsick, V.J. and Watkins, K.E. (2001) Informal and Incidental Learning. New Directions for Adult and Continuing Education, pp. 25-34, https://doi.org/10.1002/ace.5

[21] UNESCO. (2009). World Report on Investing in Cultural Diversity and Intercultural Dialogue Executive Summary, France: Paris.

[22] Bear, D. J., Tompson, H. B., Morrison, C. L., Vickers, M., Paradise, A., Czarnowsky, M., King, K. (2008). Tapping the potential of informal learning: An ASTD research study. ASTD.

[23] Tannenbaum, S. I., Beard, R. L., McNall, L. A., and Salas, E. (2010). Informal learning and development in organizations, learning, training, and development in organizations, pp. 303332.

[24] Nygren, H., Nissinen, K., Hämäläinen, R., and Wever, B. (2019). Lifelong Learning: Formal, Non-Formal and Informal Learning in the Context of the Use of Problem-Solving Skills in Technology-Rich Environments, British Journal of Educational Technology, Vol. 50, No. 4, pp. 1759-1770, https://doi.org/10.1111/bjet.12807

[25] Rogers, A. (2014). The Base of the Iceberg: Informal Learning and Its Impact on Formal and Non-formal Learning. Opladen; Berlin; Toronto: Verlag Barbara Budrich, https://doi. org/10.3224/84740632

[26] Za, S., Spagnoletti, P., and North-Samardzik, A. (2014). Organisational learning as an emerging process: The generative role of digital tools in informal learning practices,' The British Journal of Educational Technology, Vol. 45, No. 6, pp. 1023-1035, https://doi.org/ 10.1111/bjet.12211

[27] Fevre, R., Gorard, S., \& Rees, G. (2000). Necessary and unnecessary learning: The acquisition of knowledge and 'skills' in and outside employments in South Wales in the 20th century. In F. Coffield (ed). The necessity of informal learning (pp. 64-81). Great Britain: The Policy Press.

[28] Brian L. Gerber, Edmund A. Marek and Ann M. L. Cavallo (2001). Development of an informal learning opportunities assay, International Journal of Science Education, Vol. 23, No. 6, pp. 569-583, https://doi.org/10.1080/09500690116959

[29] Swanwick, T. (2005). Informal learning in postgraduate medical education: from cognitivism to 'culturism', Medical education, Vol.39, No. 8, pp. 859-865, https://doi.org/10.1111 j.1365-2929.2005.02224.x

[30] Edwards, L. J., and Muir, E. J. (2005). Promoting entrepreneurship at the University of Glamorgan through formal and informal learning, Journal of Small Business and Enterprise Development, Vol. 12, No. 4, pp. 613-626, https://doi.org/10.1108/14626000510628261 
[31] McNally, J., Blake, A., and Reid, A. (2009). The informal learning of new teachers in school, The Journal of Workplace Learning, Vol. 21, No. 4, pp. 322-333, https://doi.org/10.1108/ $\underline{13665620910954210}$

[32] Hoekstra, A., Brekelmans, M., Beijaard, D., and Korthagen, F. (2009). Experienced teachers' informal learning: Learning activities and changes in behavior and cognition, Teaching and teacher education, Vol. 25, No. 5, pp. 663-673, https://doi.org/10.1016/j.tate.2008 $\underline{.12 .007}$

[33] Lohman, M. C. (2000). Environmental Inhibitors to Informal Learning in the Workplace: A Case Study of Public School Teachers, Adult Education Quarterly, Vol. 50, No. 2, pp. 83101, https://doi.org/10.1177/07417130022086928

[34] Salim, K. R. et al. (2019). A Team-teaching model in an informal cooperative learning classroom, International Journal of Emerging Technologies in Learning (iJET), [S.l.], Vol. 14, No. 20, pp. 44-57.

[35] Bahn, D. (2007). Orientation of nurses towards formal and informal learning: Motives and perceptions, Nurse Education Today, Vol. 27, No. 7, pp. 723-730, https://doi.org/10.1016/j. nedt.2006.10.006

[36] Spaan, N. R., Dekker, A. R., van der Velden, A. W., and de Groot, E. (2016). Informal and Formal Learning of General Practitioners, Journal of Workplace Learning, Vol. 28, No. 6, pp. 378-391, https://doi.org/10.1108/jwl-12-2015-0090

[37] Chivers, G. (2011). Supporting informal learning by traders in investment banks, Journal of European Industrial Training, Vol. 35, No. 2, pp. 154-175, https://doi.org/10.1108/0309059 $\underline{1111109352}$

[38] Berg, S. A., and Chyung, S. Y. Y. (2008). Factors that influence informal learning in the workplace, The Journal of Workplace Learning, Vol. 20, No. 4, pp. 229-244, https://doi.org/ $\underline{10.1108 / 13665620810871097}$

[39] Twidale, M. B. (2005). Over the shoulder learning: supporting brief informal learning, Computer supported cooperative work (CSCW), Vol. 14, No. 6, pp. 505-547, https://doi.org/10. 1007/s10606-005-9007-7

[40] Lohman, M. C. (2006). Factors influencing teachers' engagement in informal learning activities, Journal of Workplace Learning, Vol. 18, No. 3, pp. 141-156, https://doi.org/10. $\underline{1108 / 13665620610654577}$

[41] Melber, L. M., and Cox-Petersen, A. M. (2005). Teacher professional development and informal learning environments: Investigating partnerships and possibilities, Journal of Science Teacher Education, Vol. 16, No. 2, pp. 103-120, https://doi.org/10.1007/s10972-0052652-3

[42] Schürmann, E., and Beausaert, S. (2016). What are drivers for informal learning? European Journal of Training and Development, Vol. 40, No. 3, pp. 130-154, https://doi.org/10.1108/ ejtd-06-2015-0044

[43] Martin, L. M. (2004). An emerging research framework for studying informal learning and schools, Science Education, Vol. 88, No.S1, pp. S71-S82, https://doi.org/10.1002/sce.20020

[44] Svensson, L., Ellstrom, P. E., and Aberg, C. (2004). Integrating Formal and Informal Learning at Work, Journal of Workplace Learning, Vol. 16, No. 8, pp. 479-491, https://doi.org/10. 1108/13665620410566441

[45] Sorte, S. R., and Rathod, S. B. (2016). Medical Education/Original Article Social Networking Sites As Informal Learning Tool, Indian J Physiol Pharmacol, Vol. 60, No. 4, pp. 403406.

[46] Akkara, S., Anumula, V., and Mallampalli, M. (2020). Impact of WhatsApp interaction on improving L2 speaking skills. International Journal of Emerging Technologies in Learning (iJET), Vol. 15, No. 3, pp. 250-259, https://doi.org/10.3991/ijet.v15i03.11534 
[47] Fahr, R. (2005). Loafing or learning? - the demand for informal education, European Economic Review, Vol. 49, No. 1, pp. 75-98, https://doi.org/10.1016/j.euroecorev.2004.03.002

[48] Edwards, L. J., and Muir, E. J. (2005). Promoting entrepreneurship at the University of Glamorgan through formal and informal learning, Journal of Small Business and Enterprise Development, Vol. 12, No. 4, pp. 613-626, https://doi.org/10.1108/14626000510628261

[49] Rehm, M., and Notten, A. (2016). Twitter as an informal learning space for teachers!? The role of social capital in Twitter conversations among teachers, Teaching and Teacher Education: An International Journal of Research and Studies, Vol. 60, No. 1, pp. 215-223, https://doi.org/10.1016/j.tate.2016.08.015

[50] Nehiri, N., and Aknin, N. (2021). A proposed learner's data model: integrating informal learning and enhancing personalization and interoperability. International Journal of Emerging Technologies in Learning (iJET), Vol. 16, No.8. pp. 173-187, https://doi.org/10.3991/ ijet.v16i08.19833

[51] Kantardzic, M. (2011). Data mining: Concepts, models, methods, and algorithms (2nd ed.). John Wiley \& Sons.

[52] Shin, E. K., Kim, S. H., and Hyun, Y. S. (2018). A study about the research trends of informal learning for adult, The Korean Journal of Human Resource Development Quarterly, Vol. 20, No. 1, pp. 1-38.

[53] Holmes, J. A. (2011). Informal learning: Student achievement and motivation in science through museum-based learning, Learning Environments Research, Vol. 14, No. 3, pp. 263277, https://doi.org/10.1007/s10984-011-9094-y

[54] Rogoff, B., Callanan, M., Gutierrez, K. D., and Erickson, F. (2016). The organization of informal learning, Review of Research in Education, Vol. 40, No. 1, pp. 356-401, https:// doi.org/10.3102/0091732x16680994

[55] Vizcaíno-Verdú, A., Contreras-Pulido, P., and Guzmán-Franco, M. D. (2019). Reading and informal learning trends on YouTube: The booktuber, Comunicar. Media Education Research Journal, Vol. 27, No. 1, https://doi.org/10.3916/c59-2019-09

[56] Swanwick, T. (2005). Informal learning in postgraduate medical education: from cognitivism to 'culturism', Medical education, Vol.39, No. 8, pp. 859-865, https://doi.org/10. $\underline{1111 / \mathrm{j} .1365-2929.2005 .02224 . \mathrm{x}}$

[57] Cerasoli, C. P., Alliger, G. M., Donsbach, J. S., Mathieu, J. E., Tannenbaum, S. I., and Orvis, K. A. (2018). Antecedents and Outcomes of Informal Learning Behaviors: a Meta-Analysis, Journal of Business and Psychology, Vol. 33, No. 2, pp. 203-230, https://doi.org/10.1007/ $\underline{\text { s10869-017-9492-y }}$

\section{$7 \quad$ Authors}

Kyung-Hee Park is an assistant professor in department of education at Woosuk University in South Korea, special areas of expertise in lifelong education and global citizenship education.

He $\mathbf{~} \mathbf{i}$ is a PhD candidate in department of education at Woosuk University in South Korea, works a lecturer at Sias University in China.

Nan Luo is a master student in department of education at Woosuk University in South Korea, was a technician in department of human resource at Wuchang Shipbuilding Industry Company in China.

Article submitted 2021-05-01. Resubmitted 2021-06-04. Final acceptance 2021-06-04. Final version published as submitted by the authors. 